\title{
Differences in Glucose Recognition by Individual Rat Pancreatic B Cells Are Associated with Intercellular Differences in Glucose-induced Biosynthetic Activity
}

\author{
Rita Kiekens, Peter In 't Veld, * Tania Mahler, ${ }^{*}$ Frans Schuit, ${ }^{*}$ Marnix Van De Winkel, and Daniel Pipeleers \\ Department of Metabolism and Endocrinology, ${ }^{*}$ Department of Experimental Pathology, and ${ }^{\ddagger}$ Department of Biochemistry, \\ Vrije Universiteit Brussel, B-1090 Brussels, Belgium
}

\begin{abstract}
In vitro incubated rat islet $B$ cells differ in their individual rates of protein synthesis. The number of cells in biosynthetic activity increases with the glucose concentration. Flow cytometric monitoring of the cellular redox states indicated that islet $B$ cells differ in their individual metabolic responsiveness to glucose. A shift from basal to increased NAD(P)H fluorescence occurred for $18 \%$ of the cells at $1 \mathrm{mM}$ glucose, for $43 \%$ at 5 $\mathrm{mM}$, and for $\mathbf{7 0} \%$ at $20 \mathrm{mM}$. The functional significance of this metabolic heterogeneity was assessed by comparing protein synthesis in metabolically responsive and unresponsive subpopulations, shortly after their separation by autofluorescenceactivated cell sorting. The glucose-sensitive subpopulation exhibited four- to fivefold higher rates of insulin synthesis during 60-min incubations at 2.5-10 $\mathrm{mM}$ glucose. Its higher biosynthetic activity was mainly caused by recruitment of cells into active synthesis and, to a lesser extent, by higher biosynthetic activity per recruited cell. Cells from the glucose-sensitive subpopulation were larger, and presented a threefold higher density of a pale secretory vesicle subtype, which is thought to contain unprocessed proinsulin. It is concluded that intercellular differences in metabolic responsiveness result in functional heterogeneity of the pancreatic B cell population. (J. Clin. Invest. 1992. 89:117-125.) Key words: cellular heterogeneity • insulin synthesis • islet cells $\bullet$ endocrine pancreas • metabolic redox state
\end{abstract}

\section{Introduction}

Glucose exerts a tight control on the release of insulin from the endocrine pancreas. The sugar has been found to stimulate several steps in the formation of insulin and its release by pancreatic B cells (1-3). Not all cells appear, however, equally involved in the process of glucose-induced insulin biosynthesis (4). At low glucose levels, only a minority of islet B cells is actively involved in protein synthesis (4). Glucose dose-dependently increases the number of active cells and hence the rate at which insulin is synthesized by the total population (4). The sigmoidal shape of the dose response curves in glucose-exposed

Part of this work was presented at the 25th Congress of the European Diabetes Association, Lisbon, 1989.

Address correspondence to Daniel Pipeleers, Department of Metabolism and Endocrinology, Vrije Universiteit Brussel, Laarbeeklaan 103, B-1090 Brussels, Belgium. 1991.

Received for publication 6 May 1991 and in revised form 28 August

J. Clin. Invest.

(c) The American Society for Clinical Investigation, Inc.

0021-9738/92/01/0117/09 \$2.00

Volume 89, January 1992, 117-125
B cell preparations may thus result, at least in part, from a dose-dependent recruitment of cells into a biosynthetic activity (4). The recognition of intercellular differences in the biosynthetic activity of glucose-exposed B cells also suggests that the cells markedly differ in the sensitivity of their glucose-driven metabolic pathways. The present study examines this possibility and assesses whether variations in cellular thresholds for glucose metabolism can explain the intercellular differences in glucose-induced protein synthesis. The experiments were conducted on purified rat islet B cells that are isolated by autofluorescence-activated cell sorting $(5,6)$. This model offers the possibility of measuring the glucose-induced changes in the metabolic redox state of individual cells (7). It can be used to separate B cell (sub)populations which differ in their metabolic handling of glucose and which can then be compared for their respective biosynthetic activities.

\section{Methods}

Preparation of rat pancreatic beta cells. Pancreatic islets were isolated from male adult Wistar rats (200-300 g) according to a modification of the collagenase digestion method of Lacy and Kostianovsky $(6,8)$. They were dissociated in a $\mathrm{Ca}^{2+}$-free medium containing trypsin and DNase (9). The islet cell suspensions were then submitted to autofluorescence-activated cell sorting, using cellular light scatter and flavin adenine dinucleotide autofluorescence as separation parameters $(5,6)$. This technique allows purification of single insulin-containing B cells with a yield of $2-3.10^{5}$ cells per adult rat pancreas (6).

Flow analysis of metabolic alterations in glucose-exposed B cells. We have previously described how the metabolic redox state can be measured in purified B cells (7). Samples of $5.10^{4}$ cells were incubated for $15 \mathrm{~min}$ at $37^{\circ} \mathrm{C}$ in the presence of different glucose concentrations. They were then analyzed for their light scatter and NAD(P)H-autofluorescence, using a FACS ${ }^{\circledR}$-IV flow cytometer (Becton Dickinson \& Co., Mountain View, CA) equipped with an argon laser (Spectra Physics Inc., Mountain View, CA). Excitation occurred at 351-363 nm, emission was measured between 400 and $470 \mathrm{~nm}$ (7). The FACS ${ }^{\circledR}$-data are represented as dot plots with the relative cellular autofluorescence intensity in the ordinate and the relative cellular light scatter in the abcissa (Fig. 1). The two internal controls consisted of islet B cells incubated at $1 \mathrm{mM}$ or at $20 \mathrm{mM}$ glucose; their respective dot plots were used to select the glucose-unresponsive and the glucose-responsive cells according to their distinct autofluorescence intensities (see Results). Windows were set on the basis of mean autofluorescence intensities \pm 2 SD and on the basis of the forward light scatter of single islet B cells (see Results). FACS ${ }^{\otimes}$ analysis determined the percent particles that were collected in each of the two preselected windows. A total of $5.10^{4}$ cells was analyzed per experiment, each condition being examined in at least six independent experiments. Results were expressed as mean $\pm \mathrm{SD}$, and statistically analysed using paired Student's $t$ testing.

Comparative studies on islet $B$ cells with different metabolic responsiveness to glucose. Purified B cells were incubated for $15 \mathrm{~min}$ at $37^{\circ} \mathrm{C}$ in the presence of $7.5 \mathrm{mM}$ glucose. They were then analyzed for their light scattering properties and cellular $\mathrm{NAD}(\mathrm{P}) \mathrm{H}$-autofluorescence intensity. Cells appearing in the preset windows of high and low $\mathrm{NAD}(\mathrm{P}) \mathrm{H}$ cells were isolated and considered as subpopulations of, re- 
Glucose $1 \mathrm{mM}$

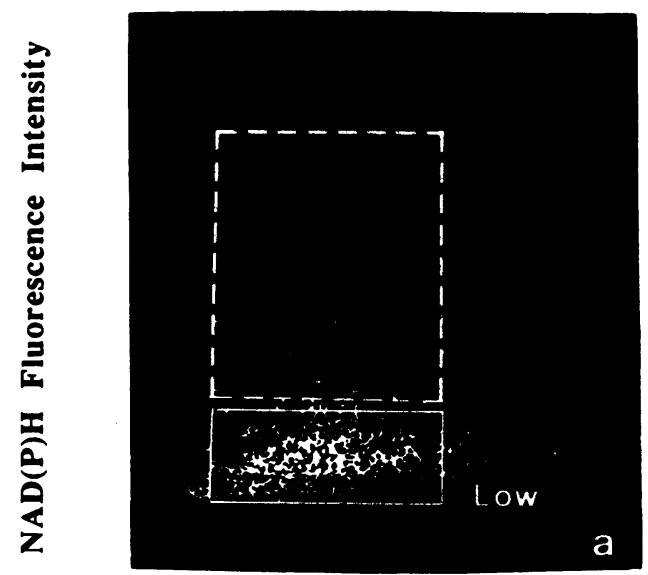

Glucose $20 \mathrm{mM}$

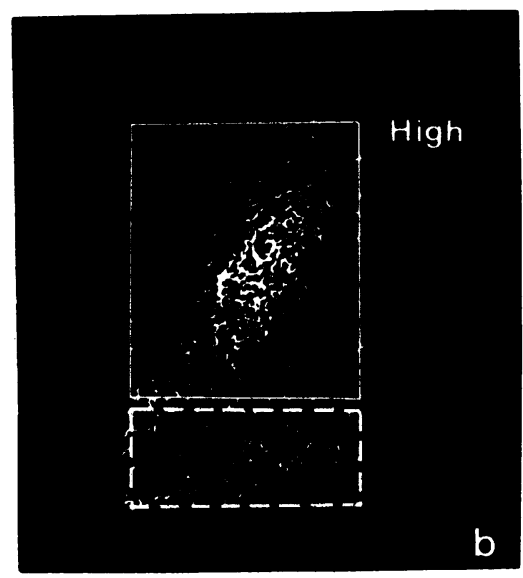

Glucose $7.5 \mathrm{mM}$

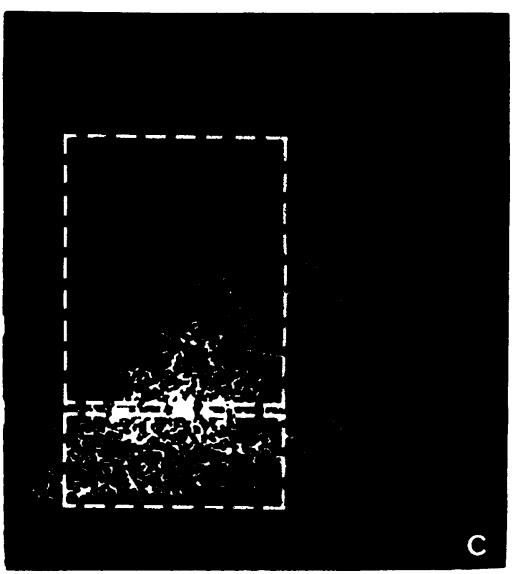

\section{Forward Scatter}

Figure 1. Dot plots after $\mathrm{FACS}^{\circledR}$-analysis of single purified B cells which have been exposed for $15 \mathrm{~min}$ to 1,20 , and $7.5 \mathrm{mM}$ glucose. The cells were examined for their NAD(P)H autofluorescence intensity (ordinate) and their forward scatter (abcissa). In the 1 and $20 \mathrm{mM}$ condition, the windows of, respectively, low and high $\mathrm{NAD}(\mathrm{P}) \mathrm{H}$ autofluorescence were set as described under Results (solid line). These windows were then used to determine the percent unresponsive (low) and responsive (high) cells in each condition (broken line).

spectively, $7.5 \mathrm{mM}$ glucose-responsive and unresponsive cells. The two subpopulations were compared for their structural and functional properties. Cell viability was examined by vital staining with neutral red (6), the percent living cells being counted immediately after isolation as well as after a 10-d culture period in polylysine-coated microtiter cups. Structural integrity was also assessed by electron microscopy on glutaraldehyde-fixed cells (6). The mean insulin content of the isolated cells was measured in acetic acid extracts of samples of $10^{4}$ cells $(6)$. The biosynthetic activity of the cells was determined over 60 -min incubations, immediately after their isolation.

Analysis of protein biosynthesis in isolated islet B cells. Samples of $5.10^{4}$ islet B cells were incubated for $60 \mathrm{~min}$ at different glucose concentrations in $200 \mu$ l Earle's-Hepes medium containing $1 \%(\mathrm{wt} / \mathrm{vol})$ BSA (fraction V, RIA grade; Sigma Chemical Co., St. Louis, MO) and $50 \mu \mathrm{Ci} \mathrm{L}-\left(3,5-{ }^{3} \mathrm{H}\right)$-tyrosine (sp act $50 \mathrm{Ci} / \mathrm{mmol}$; total tyrosine concentration $5 \mu \mathrm{M}$; Amersham International, Amersham, Bucks, UK) (10). Under these conditions the rate of insulin biosynthesis can be expressed as $\mathrm{fmol} / \mathrm{h} \mathrm{(10)}$. At the end of the incubation, the cells were washed in Earle's-Hepes buffer containing $1 \mathrm{mM}$ unlabeled L-tyrosine and then extracted in acetic acid or processed for autoradiography.

Acid extracts were prepared in $2 \mathrm{M}$ acetic acid containing $0.25 \%$ BSA. Samples were dried and assayed for ${ }^{3} \mathrm{H}$-protein as well as for total and ${ }^{3} \mathrm{H}$-labeled insulin immunoreactivity (4). The content in ${ }^{3} \mathrm{H}$-protein was obtained by counting the TCA precipitable radioactivity. The ${ }^{3} \mathrm{H}$-labeled insulin immunoreactivity was assayed by adding an excess of guinea pig antiinsulin serum and precipitating the immune complexes with protein A-Sepharose; nonspecific binding was measured in samples receiving normal guinea pig serum instead of antiinsulin serum (4). The ${ }^{3} \mathrm{H}$-labeled insulin immunoreactivity was extracted from the immunoprecipitated complexes with $2 \mathrm{M}$ acetic acid and counted. The acid cell extracts were also further analyzed by gel chromatography. Samples were eluted on Biogel P-10 columns (Bio-Rad Laboratories, Richmond, CA) with $2 \mathrm{M}$ acetic acid, $0.25 \% \mathrm{BSA}$ as running solution (11). Elution fractions were counted and plotted against ${ }^{125} \mathrm{I}$-insulin standards; the two ${ }^{3} \mathrm{H}$-labeled peaks were completely immunoprecipitable with an insulin antibody and the second peak coincided with the insulin immunoreactive fraction of the cell extract.

Autoradiographs were developed as described by Schuit et al. (4). Briefly, the ${ }^{3} \mathrm{H}$-labeled cell preparations were fixed for $30 \mathrm{~min}$ in $2 \%$ p-formaldehyde, washed with PBS containing 0.1\% BSA, and dried overnight on poly(L-lysine)-coated glass slides. The cells were then postfixed for $15 \mathrm{~min}$ in $2 \%$ glutaraldehyde and washed with distilled water. The slides were exposed for $90 \mathrm{~min}$ to an autoradiographic emulsion (L-4; Ilford Ltd., Basildon, Essex, UK), which was developed for $7 \mathrm{~min}$ in ID-11 (Ilford) at $20^{\circ} \mathrm{C}$ and then fixed for another $7 \mathrm{~min}$ in Hypam (Ilford). The cell preparations were counterstained with hematoxylin. A total of at least 125 cells were analyzed per condition. Analysis consisted in counting the number of silver grains per cell at a screen magnification of 5,800 using contrast-enhanced video microscopy. As it was not possible to count the grains in cells with a high grain density, cells with more than 40 grains were considered as one group. Within an experiment a cell was considered to be biosynthetically activated when

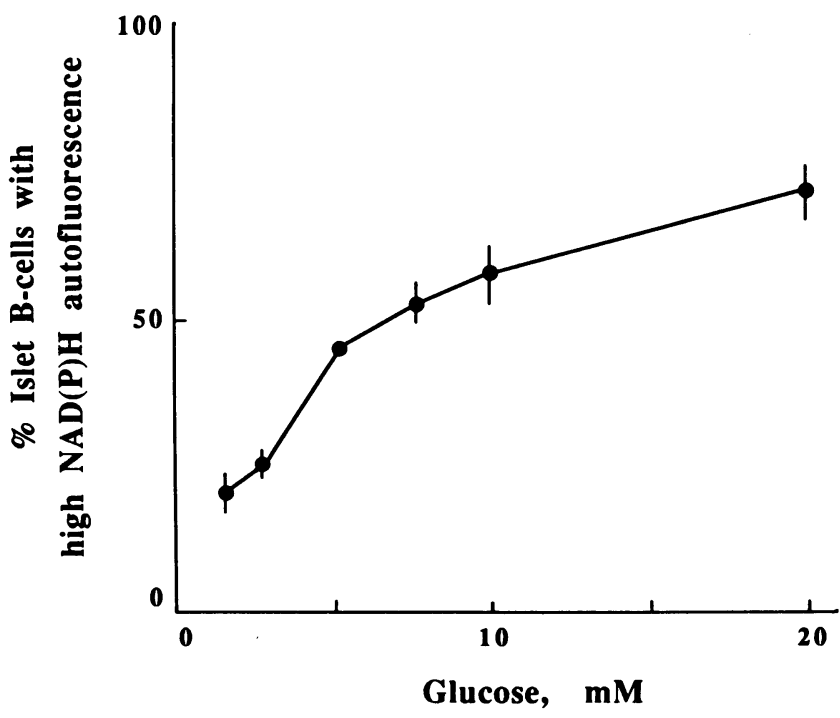

Figure 2. Dose-response curve for the effect of glucose on the percent $B$ cells with high $\mathrm{NAD}(\mathrm{P}) \mathrm{H}$ autofluorescence. Data represent mean values \pm SEM of 6 to 18 experiments. 

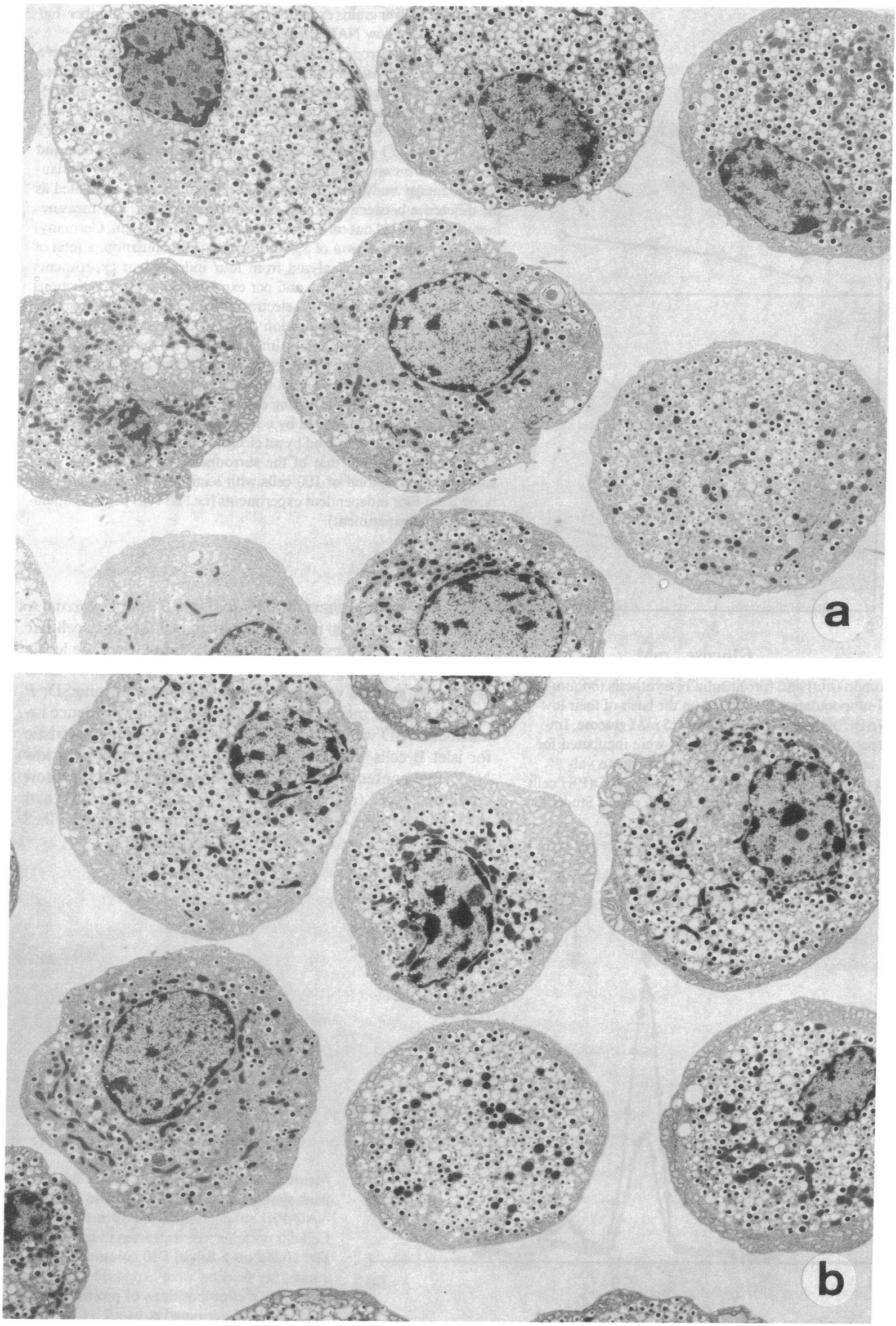

Figure 3. Electron micrographs of B cells recovered in the high $(a)$ and low $(b)$ NAD(P)H autofluorescence windows after 15 min of exposure to $7.5 \mathrm{mM}$ glucose. The cells from both subpopulations exhibit an intact ultrastructure. 


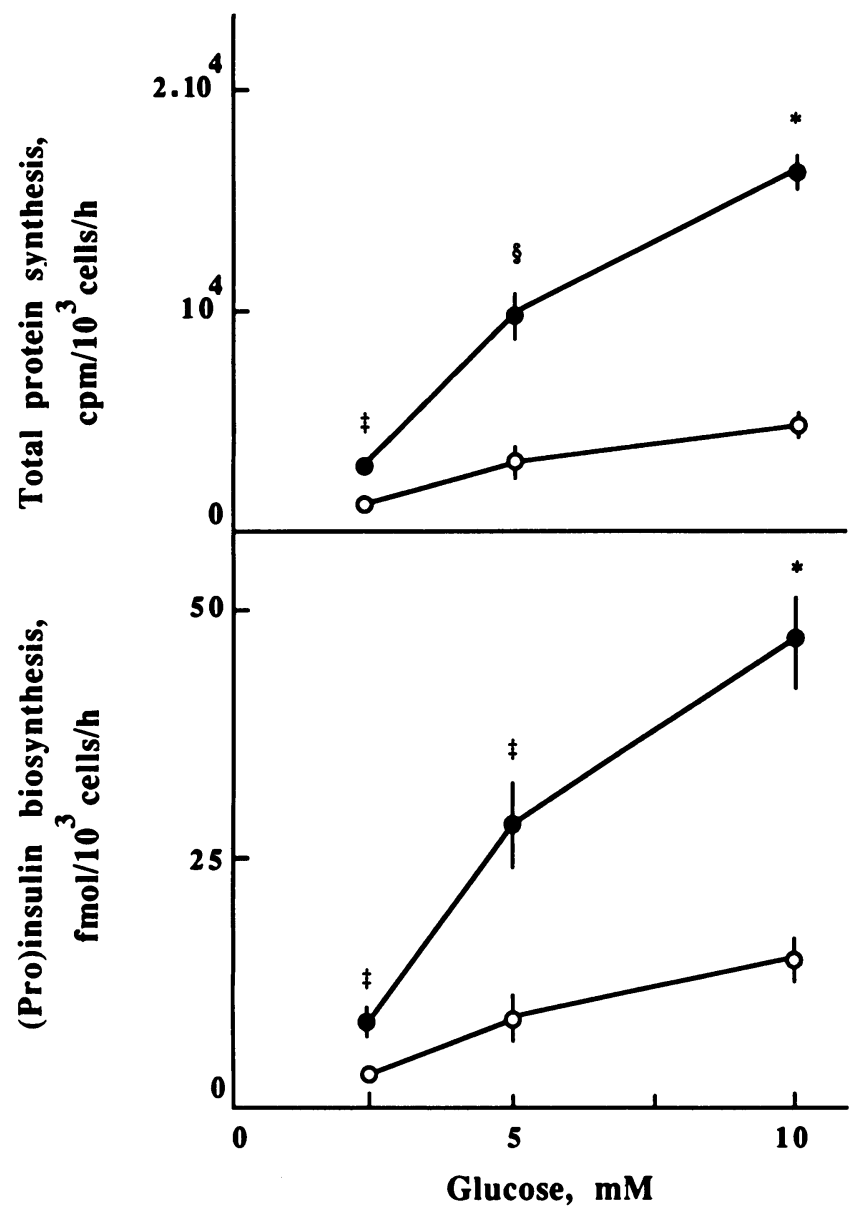

Figure 4. Total protein (top) and (pro)insulin biosynthesis (bottom) in the two islet B cell subpopulations separated on the basis of their low (O) and high (๑) NAD(P)H autofluorescence at $7.5 \mathrm{mM}$ glucose. Immediately after separation, the two preparations were incubated for $60 \mathrm{~min}$ at $2.5,5$, or $10 \mathrm{mM}$ glucose. Data represent mean values \pm SEM of eight to nine experiments. Low and high NAD(P)H cells were compared at the same glucose concentration by paired Student's $t$ test. ${ }^{*} P<0.001 ;{ }^{\ddagger} P<0.005 ;{ }^{8} P<0.01$. its number of silver grains exceeded the mean $+2 \mathrm{SD}$ of the number that was found in the low NAD(P)H cells labeled at $1.4 \mathrm{mM}$ glucose.

Electron microscopic analysis. The two subpopulations that were separated on the basis of their (un)responsiveness to $7.5 \mathrm{mM}$ glucose were fixed in $2.5 \%$ glutaraldehyde (prepared in $0.1 \mathrm{M}$ sodium cacodylate $\mathrm{pH} 7.4$ ), postfixed in $1 \%$ osmium tetroxide, and stained en bloc with $1 \%$ uranylacetate before being dehydrated and embedded in Spurr's resin. Sections of $1 \mu \mathrm{m}$ thickness were stained with methylene blue and then used for measuring total and nuclear cell surface areas by semiautomatic image analysis. Cytoplasmic surface areas were calculated as the difference between total and nuclear surface areas. The measurements were carried out on a Videoplan (Zeiss, Oberkochen, Germany) at a screen magnification of 5,800 . For each subpopulation, a total of 400 cell profiles were analyzed from four independent experiments (100 cells per subpopulation and per experiment). Ultrathin sections were examined in a Zeiss 9S2 electron microscope, and micrographs were taken at a final magnification of 17,300 . The micrographs were also submitted to semiautomatic image analysis for the counting of the number of secretory vesicles per cytoplasmic surface area. Analysis was restricted to vesicles with a sectioned granule core. A distinction was made between vesicles containing dark and pale granule cores. A pale secretory granule was defined by a large core, occupying at least twothirds of the vesicle area, and by an electron density that was comparable to, or lower than, that of the surrounding cytoplasm. For each subpopulation, a total of 100 cells with sectioned nucleus were analyzed from four independent experiments (i.e., 25 cells per subpopulation and per experiment).

\section{Results}

Metabolic responsiveness of individual islet B cells to glucose. A 15-min exposure to $20 \mathrm{mM}$ glucose increased the mean cellular NAD(P)H-autofluorescence intensity threefold over the levels measured at $1 \mathrm{mM}$ glucose $(78 \pm 14$ relative fluorescence units at $20 \mathrm{mM}$ glucose vs. $26 \pm 6$ at $1 \mathrm{mM}$ glucose; mean $\pm \mathrm{SD}, P$ $<0.001)$. These mean cellular NAD(P)H autofluorescence intensities \pm 2 SD were taken to delineate the areas characteristic for islet B cells with a high (Fig. $1 b$, high) and with a low $\mathrm{NAD}(\mathrm{P}) \mathrm{H}$ content (Fig. $1 a$, low). The low NAD(P)H window contained $82 \pm 7($ mean $\pm \mathrm{SD}, n=18)$ percent of the cells at 1 $\mathrm{mM}$ glucose, the high $\mathrm{NAD}(\mathrm{P}) \mathrm{H}$ window collected $70 \pm 8$

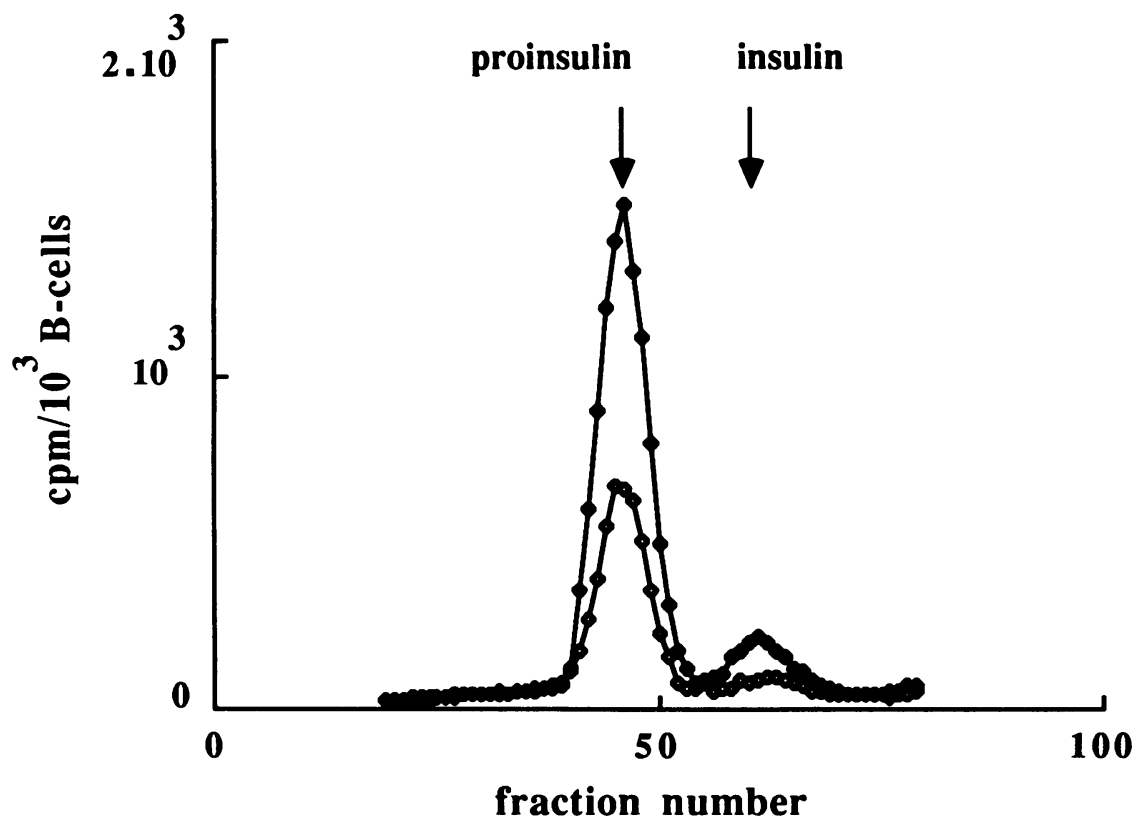

Figure 5. Elution pattern of ${ }^{3} \mathrm{H}$-labeled proteins synthesized in the low (0) and high (•) $\mathrm{NAD}(\mathrm{P}) \mathrm{H}$ subpopulations at $10 \mathrm{mM}$ glucose. Cellular proteins were extracted in acetic acid and eluted on a Biogel P10 column. The counts per fraction were expressed per $10^{3}$ cells. The elution positions of proinsulin and insulin were determined as in ref. 11. 
(mean $\pm \mathrm{SD}, n=7$ ) percent at $20 \mathrm{mM}$. Analysis of the individual cell responses to $20 \mathrm{mM}$ glucose indicated that not all glucose-exposed B cells showed an increase in $\mathrm{NAD}(\mathrm{P}) \mathrm{H}$ content: $30 \pm 8$ percent (mean $\pm S D$ ) remained in the window of cells with low cellular $\mathrm{NAD}(\mathrm{P}) \mathrm{H}$ levels (Fig. $1 b$, broken line). On the other hand, $18 \pm 7$ (mean $\pm \mathrm{SD}$ ) percent of the cells analyzed at 1 $\mathrm{mM}$ glucose appeared within the window of cells with high cellular NAD(P)H content (Fig. $1 a$, broken line). These results indicate the existence of a heterogeneity in the metabolic redox state of individual B cells, whether these cells are examined at 1 or at $20 \mathrm{mM}$ glucose. They also demonstrate that glucose increases the number of islet $B$ cells with high NAD(P)H content. To determine the dose responsiveness of this glucose effect, we measured the percent of pancreatic $B$ cells with high NAD(P)H autofluorescence after $15 \mathrm{~min}$ exposure to four intermediate glucose concentrations. It was found that glucose increased, dose-dependently, the number of cells falling within the high $\mathrm{NAD}(\mathrm{P}) \mathrm{H}$ window, the sharpest rise being noticed between 2.5 and $5 \mathrm{mM}$ glucose (Fig. 2). At $7.5 \mathrm{mM}$ glucose, $\sim 50 \%$ of the cells were recovered within the high $\mathrm{NAD}(\mathrm{P}) \mathrm{H}$ window. This percentage was slightly higher at $10 \mathrm{mM}$ glucose $(56 \pm 7)$ and rose to $70 \pm 3$ percent at $20 \mathrm{mM}$. It was not tested whether glucose concentrations above $20 \mathrm{mM}$ were able to further increase this percentage. In addition to increasing the number of cells with elevated $\mathrm{NAD}(\mathrm{P}) \mathrm{H}$ level, glucose also raised the $\mathrm{NAD}(\mathrm{P}) \mathrm{H}$ fluorescence intensity of metabolically responsive cells. This effect was most marked above $7.5 \mathrm{mM}$ glucose as evidenced by the higher mean autofluorescence intensity of the "high" cells at $20 \mathrm{mM}$ than those at 1 or $7.5 \mathrm{mM}$ glucose (Fig. 1).

Preparation of islet B cells subpopulations with different metabolic responsiveness to glucose. To compare the functional properties of islet B cells with different metabolic responsiveness to glucose, we separated the cells according to their $\mathrm{NAD}(\mathrm{P}) \mathrm{H}$-autofluorescence intensity at $7.5 \mathrm{mM}$ glucose. This concentration was selected in view of the equal size of the sub-

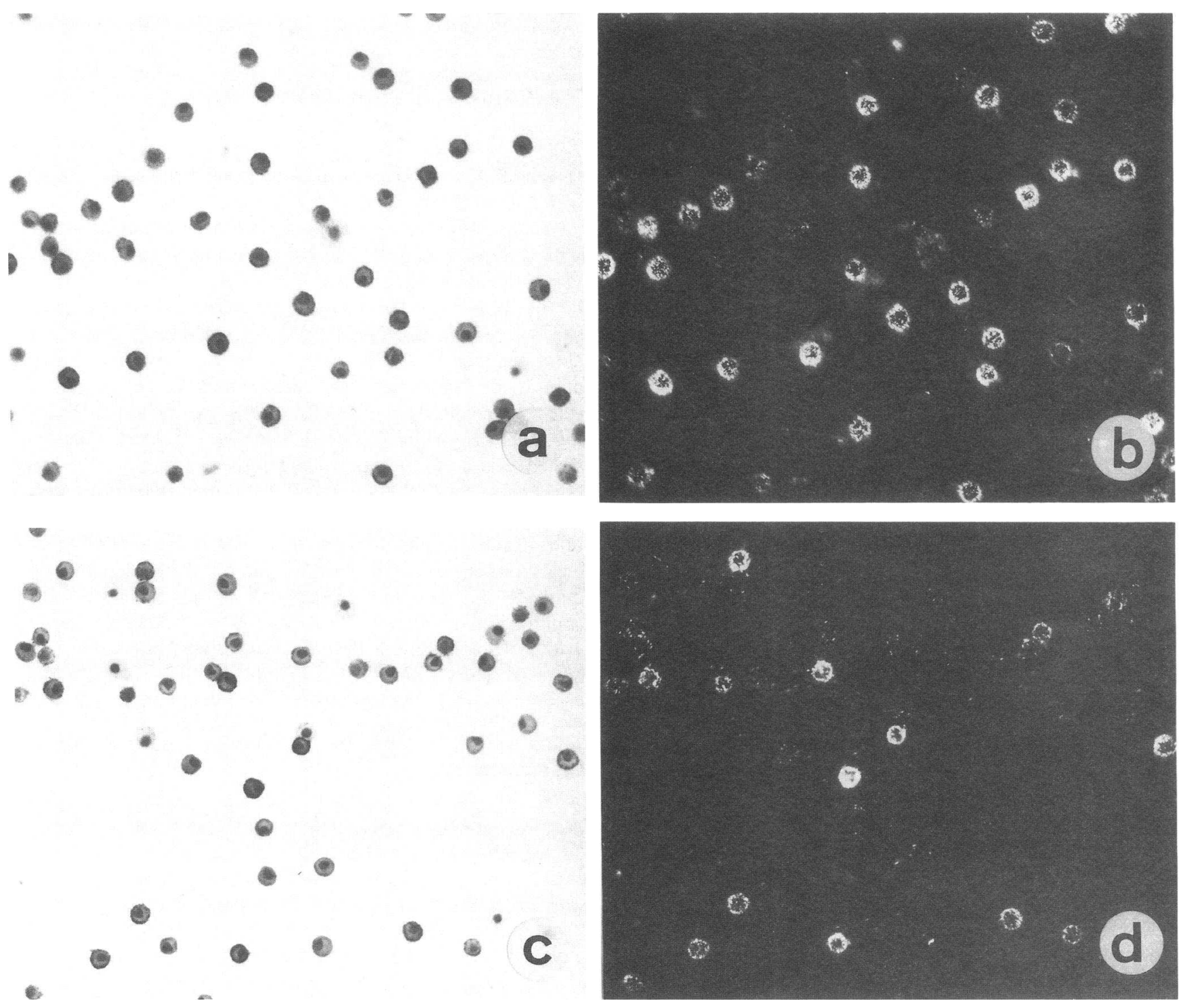

Figure 6. Autoradiographs of high $(a$ and $b)$ and low $(c$ and $d)$ NAD(P)H cells incubated with ${ }^{3} \mathrm{H}$-tyrosine for 60 min at $7.5 \mathrm{mM}$ glucose. The cells were photographed in normal $(a-c)$ and epipolarization $(b-d)$ microscopy. The high NAD(P)H subpopulation contained a higher percent densely labeled cells than the low NAD(P)H subpopulation. 
populations collected in the low and high $\mathrm{NAD}(\mathrm{P}) \mathrm{H}$ windows (Figs. 1 and 2). Under this condition, sufficient cell numbers were collected from the low and high windows to undertake the proposed experiments. This would not have been possible in the $1 \mathrm{mM}$ or $20 \mathrm{mM}$ condition. On the other hand, the two subpopulations, separated at $7.5 \mathrm{mM}$ and further denoted as low and high $\mathrm{NAD}(\mathrm{P}) \mathrm{H}$ cells, differ less in their mean fluorescence intensity, than the low and high subpopulation at 20 $\mathrm{mM}$. This is less optimal for detecting functional differences that are associated to cellular differences in redox state.

Immunocytochemistry of the low and high $\mathrm{NAD}(\mathrm{P}) \mathrm{H}$ cells showed that both fractions contained $>95 \%$ insulin-positive cells (data not shown). This degree of purity was confirmed by electron micrographs illustrating ultrastructurally intact and well granulated cells in both preparations (Fig. 3). Staining with neutral red indicated a comparable viability $(>90 \%)$ of both subpopulations immediately after their isolation; the two cell groups survived equally well during a 10-d culture period (data not shown).

Comparison of glucose-induced protein biosynthesis in islet $B$ cell subpopulations with different metabolic responsiveness to glucose. The two islet B cell subpopulations that were separated according to their distinct $\mathrm{NAD}(\mathrm{P}) \mathrm{H}$-autofluorescence at 7.5 $\mathrm{mM}$ glucose, were compared for their protein biosynthetic activity during a 60 -min incubation at different glucose concentrations. At $2.5 \mathrm{mM}$ glucose, the high $\mathrm{NAD}(\mathrm{P}) \mathrm{H}$ cells incorporated fourfold more ${ }^{3} \mathrm{H}$-tyrosine into total protein than the low $\mathrm{NAD}(\mathrm{P}) \mathrm{H}$ cells (Fig. 4). Their rate of insulin biosynthesis was almost fivefold higher $\left(7.2 \pm 1.5 \mathrm{fmol} / 10^{3}\right.$ cells per $\mathrm{h}$ vs. $1.5 \pm 0.4$ fmol $/ 10^{3}$ cells per $h$ in the low $N A D(P) H$ preparation, mean \pm SEM, $n=9, P<0.005$ ) (Fig. 4). Raising the glucose concentration to 5 and $10 \mathrm{mM}$ resulted, in both preparations, in a dose-dependent increase in the respective rates of protein and proinsulin biosynthesis (Fig. 4). The biosynthetic rates in high $\mathrm{NAD}(\mathrm{P}) \mathrm{H}$ cells remained three to fourfold higher than those in low $\mathrm{NAD}(\mathrm{P}) \mathrm{H}$ cells. In both subpopulations, $60 \%$ of the ${ }^{3} \mathrm{H}$-total protein fraction at 10 and $20 \mathrm{mM}$ glucose, corresponded to newly formed (pro)insulin. When the ${ }^{3} \mathrm{H}$-labeled material was eluted over a Biogel P-10 column, most of the newly formed proteins were recovered in the proinsulin peak (Fig. 5). No difference was observed in the respective proportions of the insulin peaks: $11 \pm 2 \%$ of ${ }^{3} \mathrm{H}$-IRI in the low $\mathrm{NAD}(\mathrm{P}) \mathrm{H}$ cells and $12 \pm 3 \%$ in the high $\mathrm{NAD}(\mathrm{P}) \mathrm{H}$ cells (Fig. 5).

The ${ }^{3} \mathrm{H}$-labeled $\mathrm{B}$ cell preparations were also examined in autoradiographs to determine the percent cells which have contributed to the measured biosynthetic activities (Fig. 6). At 1.4 $\mathrm{mM}$ glucose, $20 \pm 4 \%$ of high $\mathrm{NAD}(\mathrm{P}) \mathrm{H}$-cells were involved in protein synthesis, versus only $7 \pm 2 \%$ of low $\mathrm{NAD}(\mathrm{P}) \mathrm{H}$ cells (mean \pm SEM, $n=4$, NS) (Fig. 7). Addition of glucose dose-dependently increased the number of active cells in both preparations. This glucose-induced recruitment occurred almost linearly between 1.4 and 7.5 to $10 \mathrm{mM}$ glucose. The sharpest rise was observed in high $\mathrm{NAD}(\mathrm{P}) \mathrm{H}$ cells, where the addition of 3.6 $\mathrm{mM}$ glucose to the basal medium $(1.4 \mathrm{mM})$ recruited $54 \pm 6 \%$ of the cells into protein synthesis; in low $\mathrm{NAD}(\mathrm{P}) \mathrm{H}$ cells, this rise in glucose recruited only $28 \pm 10 \%$ of the cells (mean \pm SEM, $n$ $=4, P<0.05$ ). The maximal level of cell recruitment was obtained at $7.5 \mathrm{mM}$ glucose for the high NAD(P)H cells. This resulted in a total of $87 \pm 3 \%$ active cells. In low NAD(P)H cells, a glucose concentration of $10 \mathrm{mM}$ was required for maximal cell recruitment, which resulted in $65 \pm 6 \%$ active cells

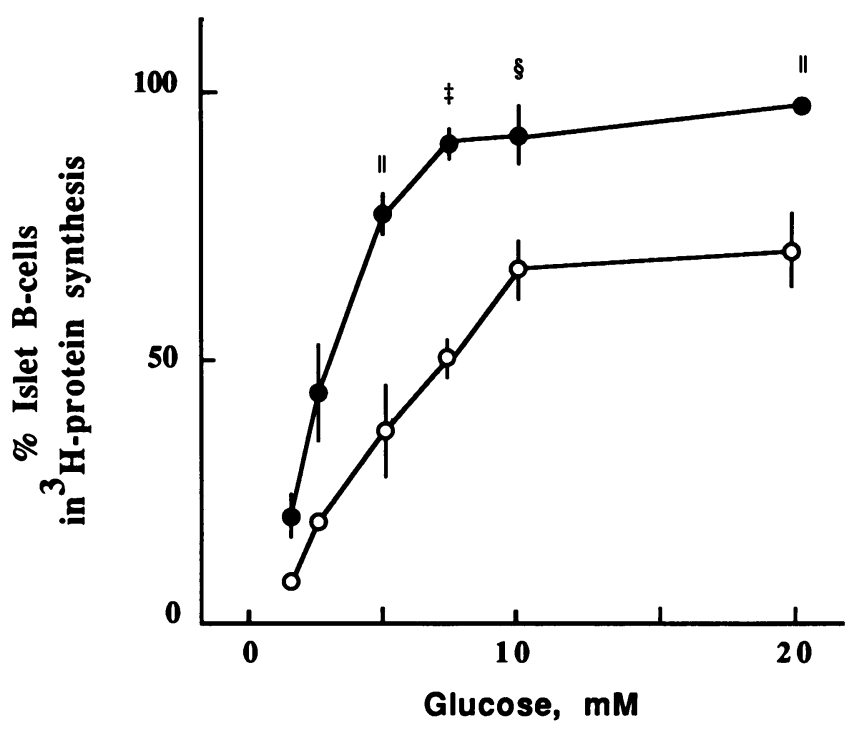

Figure 7. Effect of glucose on the percent biosynthetically activated cells in autoradiographs of low (0) and high (๑) NAD(P)H subpopulations which had been separated at $7.5 \mathrm{mM}$ glucose. Data represent mean values \pm SEM of four experiments. Low and high NAD(P)Hcells were compared at the same glucose concentration by paired Student's $t$ testing. ${ }^{\ddagger} P<0.005 ;{ }^{\S} P<0.01 ; "{ }^{\|} P<0.05$.

(mean $\pm \mathrm{SEM}, n=4$ ), a significantly lower number than in the high NAD(P)H subpopulation $(P<0.01)$ (Fig. 7).

Comparison of hormone stores in islet B cell subpopulations with different metabolic responsiveness to glucose. The observation of a lower biosynthetic activity in cells with a low metabolic responsiveness to glucose led us to compare the hormone stores in the two separated B cell subpopulations. By immunoassay, the high $\mathrm{NAD}(\mathrm{P}) \mathrm{H}$ cells were found to contain a higher amount of insulin immunoreactive material $\left(68 \pm 6 \mathrm{ng} / 10^{3}\right.$ cells) than the low $\mathrm{NAD}(\mathrm{P}) \mathrm{H}$ cells $\left(49 \pm 4 \mathrm{ng} / 10^{3}\right.$ cells, mean \pm SEM, $n=11, P<0.01)$. The high NAD(P)H cells presented also a larger cytoplasmic surface area than the low NAD(P)H cells (Table I), while the number of secretory vesicles per unit cytoplasmic area, was similar in both subpopulations (Table I). However, when the relative amount of a pale secretory vesicle subtype was compared in both preparations, markedly higher numbers per unit cytoplasmic area were counted in high NAD(P)H cells than in low NAD(P)H cells $(P$ $<0.05$, Table I and Fig. 8). Pale granules were noticed in $12 \%$ of the secretory vesicles in the high $\mathrm{NAD}(\mathrm{P}) \mathrm{H}$ subpopulation, versus only $4 \%$ in the low $\mathrm{NAD}(\mathrm{P}) \mathrm{H}$ subpopulation (Table I).

\section{Discussion}

We have previously reported that in vitro incubated islet $B$ cells do not exhibit an identical state of protein synthesis (4). Glucose increased, dose-dependently, the percent B cells with activated biosynthetic activity (4). These results indicate that islet $B$ cells differ in their individual responsiveness to glucose. The molecular basis of this cellular heterogeneity has not yet been identified. It could be located at the level of glucose handling or at the site where glucose-induced signals control translation. The present study points to the existence of intercellular differences in glucose handling. The cellular redox state was taken as 

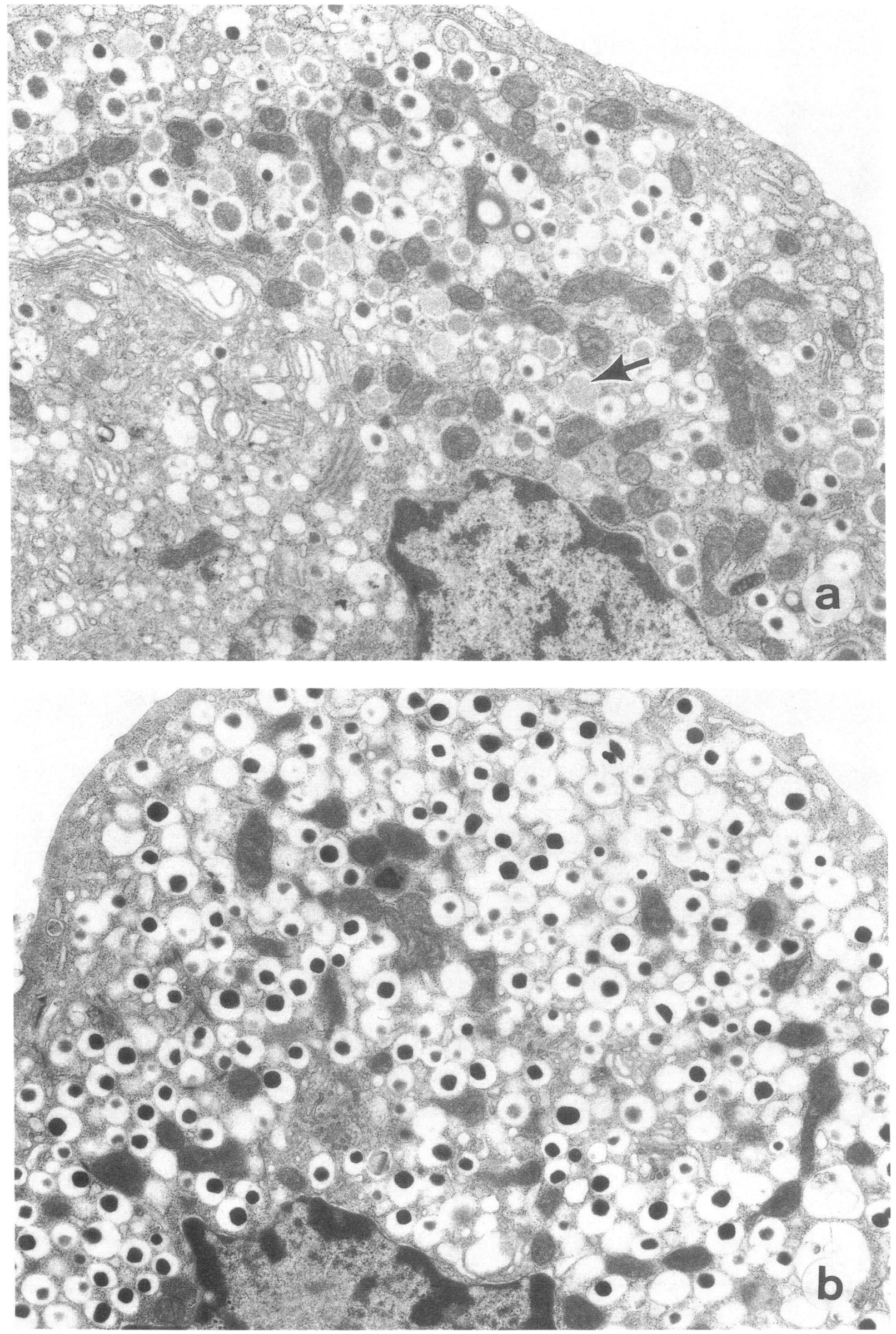

Figure 8. Electron micrographs of B cells collected in the high $(a)$ and low $(b) \mathrm{NAD}(\mathrm{P}) \mathrm{H}$-window after exposing the cells to $7.5 \mathrm{mM}$ glucose. High NAD(P)H cells display similar levels of granulation as low $\mathrm{NAD}(\mathrm{P}) \mathrm{H}$ cells, but contain a higher amount of a pale secretory vesicle subtype (arrow). 
Table I. Morphometric Comparison of Low and High NAD(P)H Cells Separated at $7.5 \mathrm{mM}$ Glucose

\begin{tabular}{llccc}
\hline & & Low & High & $P$ \\
\hline Total cell surface area & $\mu \mathrm{m}^{2} /$ cell & $106 \pm 6$ & $127 \pm 5$ & $P<0.001$ \\
Cytoplasmic surface area (CSA) & $\mu \mathrm{m}^{2} /$ cell & $81 \pm 7$ & $99 \pm 6$ & $P<0.01$ \\
Number of secretory vesicles & & & & \\
Total & $n / \mu \mathrm{m}^{2}$ C.S.A. & $1.85 \pm 0.26$ & $2.00 \pm 0.35$ & NS \\
"Pale" & $n / \mu \mathrm{m}^{2}$ C.S.A. & $0.07 \pm 0.05$ & $0.25 \pm 0.14$ & $P<0.05$ \\
& $\%$ Total & $4 \pm 2$ & $12 \pm 4$ & $P<0.01$ \\
& & & &
\end{tabular}

Results are expressed as mean $\pm \mathrm{SD}$ of four independent experiments. The number of sectioned cells per condition are indicated in Results. Differences between the values of low and high NAD(P)H cells are calculated by paired Student's $t$ test.

an index for the level of glucose metabolism. It was monitored through the cellular NAD(P)H-autofluorescence intensity, which is known to increase during the fluxes of glycolysis, the Krebs cycle, and the pentose phosphate shunt.

When pancreatic B cell populations were examined at 1 $\mathrm{mM}$ glucose, cellular NAD(P)H levels were not normally distributed, with almost $20 \%$ of the cells exhibiting higher $\mathrm{NAD}(\mathrm{P}) \mathrm{H}$ levels than the majority of cells which were clustered around values considered as basal. Short exposure to glucose dose-dependently increased the number of $B$ cells with a higher NAD(P)H autofluorescence. This glucose-induced shift in cellular metabolic redox state occurred for $5 \%$ of the cells after a rise from 1 to $2.5 \mathrm{mM}$ glucose; an additional $20 \%$ of cells responded to an increase from 2.5 to $5 \mathrm{mM}$, while $25 \%$ was only responsive between 5 and $20 \mathrm{mM}$. Pancreatic B cells thus differ in their individual thresholds for glucose-induced changes in the cellular redox state. Since glucose metabolism in islet B cells regulates the opening or closing of ionic membrane channels (12-14), the intercellular differences in metabolic threshold are likely to be associated with parallel differences in glucose-induced depolarization. The present observations can thus account for the earlier described heterogeneity in electrically recorded signals from glucose-exposed islet cells (15). In view of the well known parallellism between the rate of glucose metabolism and that of insulin synthesis $(11,16)$, the cellular heterogeneity in metabolic activity can be held responsible for the earlier observed intercellular differences in protein synthesis (4). The glucose-induced recruitment of islet B cells into a protein synthetic activity seems thus to depend on the sugar's ability to overcome the cellular thresholds in the metabolic pathways which regulate B cell function. This recruiting effect was mainly observed between 1 and $7.5 \mathrm{mM}$ glucose. Increasing the glucose concentration above $7.5 \mathrm{mM}$ rather resulted in a further rise of $\mathrm{NAD}(\mathrm{P}) \mathrm{H}$ levels in metabolically activated cells, and may thus be responsible for an amplification of functions in recruited cells.

It is presently unknown where the sites of metabolic variability are located within the insulin-producing $B$ cells. The ability to prepare islet B cell subpopulations which differ in metabolic responsiveness to glucose, makes it feasible to compare glucose responsive and unresponsive subpopulations for the expression and activities of potential key regulators such as the liver-type glucose transporter (17), glucokinase $(18,19)$, or other glucose-induced signals $(20,21)$. Such type of investigation may also indicate why a minority of adult rat islet B cells remain unresponsive to all tested glucose concentrations. Although it is difficult to exclude that this subpopulation corre- sponds to cells which have undergone some damage during the isolation procedure, we have not found any experimental evidence to support this possibility. Most cells of this fraction appear structurally intact by vital staining and electron microscopy, and survive a 10-d culture period. It is to be examined whether the glucose unresponsiveness of these cells results from the in vitro conditions during their preparation or whether it expresses the in situ metabolic state of a particular islet $B$ cell subpopulation.

The correlation between the cellular metabolic responsiveness to glucose and its biosynthetic activity became evident by comparing glucose responsive and unresponsive subpopulations. Metabolically different subpopulations were prepared on the basis of the cellular redox state at $7.5 \mathrm{mM}$ glucose. At this concentration, the distribution of cells is mainly the result of the sugar's recruiting action, i.e., a shift from basal to increased NAD(P)H levels. The majority of cells with a rapid metabolic response to $7.5 \mathrm{mM}$ glucose were also recruited into biosynthetic activity during a subsequent 60 -min incubation at this glucose concentration. Despite this relatively long incubation time, markedly less cells were recruited in the subpopulation which had failed to respond to short $7.5 \mathrm{mM}$ glucose exposure. Similar differences in recruitment were noticed when both subpopulations were incubated at lower glucose concentrations. This observation can explain the markedly lower rates of protein synthesis in the 7.5-mM unresponsive B cell preparation. When this subpopulation was incubated at higher glucose concentrations $(10 \mathrm{mM})$, its percent of recruited cells increased, but its rate of protein synthesis did not rise proportionally. Higher glucose levels can thus succeed in the recruitment of cells with poor glucose sensitivity but induce only a relatively small increase in their protein synthetic activity. One explanation for this finding could be a shortage in preproinsulin mRNA, possibly as a consequence of a chronic state of reduced glucose metabolism in these cells. It is thus conceivable that, under basal physiologic circumstances, only a subpopulation of islet B-cells is metabolically responsive to glucose and hence involved in hormone synthesis. Other islet B cells, which are not responsive to physiologic glucose concentrations, seem to participate only marginally to the process of hormone production under these circumstances, but could be activated by conditions of high metabolic demand. This view is supported by morphometric comparison of the $7.5 \mathrm{mM}$ responsive and unresponsive cells. This analysis strongly suggested that the two subpopulations had been in different states of biosynthetic activity before their isolation. High responsive cells were larger, and contained, both in absolute and relative terms, a higher 
amount of a pale secretory vesicle subtype which is shown to contain unprocessed hormone $(22,23)$. We have, so far, not detected any inhibition in the rate of proinsulin conversion in the high responsive cells, so that their higher content in pale granules may be related to the higher state of biosynthetic activity in these cells. The high responsive cells were, on the other hand, found to be more sensitive to glucose stimuli for release (24). Assuming that a higher secretory activity implies a higher release of dark, "mature" granules, this could contribute to a higher proportion of pale over dark granules in the high responsive cells. These observations favor the hypothesis that the frequency of pale granules may serve as a marker for the glucose-responsive state of islet cells in situ. Such study may help answering the question whether the in situ pancreatic B cell population is also composed of cells with different sensitivity to glucose, and hence of cells in a different state of functional activity.

\section{Acknowledgments}

The authors thank the technical staff of the Departments of Metabolism and Endocrinology, and of Experimental Pathology, Vrije Universiteit Brussels, for expert technical assistance, and N. Van Slycke for secretarial help.

This work was supported by grants from the Belgian Fund for Medical Research (3.0075.88 and 3.0093.90) and from the Belgian Ministry of Science Policy (Gekoncerteerde Aktie 86/91-102). Rita Kiekens and Tania Mahler are research fellows of the Belgian National Fund for Scientific Research.

\section{References}

1. Permutt, M. A., and D. M. Kipnis. 1972. Insulin biosynthesis. On the mechanism of glucose stimulation. J. Biol. Chem. 247:1194-1199.

2. Steiner, D. F., S. J. Chan, J. M. Welsh, D. Nielsen, J. Michael, H. S. Tager, and A. H. Rubenstein. 1986. Models of peptide biosynthesis: the molecular and cellular basis of insulin production. Clin. Invest. Med. 9:328-336.

3. Malaisse, W. J., A. Sener, A. Herchuelz, and J. C. Hutton. 1979. Insulin release: the fuel hypothesis. Metab. (Clin. \& Exp.) 28:373-386.

4. Schuit, F. C., P. A. In 't Veld, and D. G. Pipeleers. 1988. Glucose stimulates proinsulin biosynthesis by a dose-dependent recruitment of pancreatic beta cells. Proc. Natl. Acad. Sci. USA. 85:3865-3869.

5. Van De Winkel, M., E. Maes, and D. G. Pipeleers. 1982. Islet cell analysis and purification by light scatter and autofluorescence. Biochem. Biophys. Res. Commun. 107:525-532.
6. Pipeleers, D. G., P. A. In 't Veld, M. Van De Winkel, E. Maes, F. C. Schuit, and W. Gepts. 1985. A new in vitro model for the study of pancreatic A and B cells. Endocrinology. 117:806-816.

7. Van De Winkel, M., and D. Pipeleers. 1983. Autofluorescence-activated cell sorting of pancreatic islet cells: purification of insulin-containing B-cells according to glucose-induced changes in cellular redox state. Biochem. Biophys. Res. Commun. 114:835-842.

8. Lacy, P. E., and H. Kostianovsky. 1967. Method for the isolation of intact islets of Langerhans from the rat pancreas. Diabetes. 16:35-39.

9. Pipeleers, D. G., and M. A. Pipeleers-Marichal. 1981. A method for the purification of single A, B and D cells and for the isolation of coupled cells from isolated rat islets. Diabetologia. 20:654-663.

10. Schuit, F., and D. Pipeleers. 1990. Measuring the balance between insulin biosynthesis and release. Diabetologia. 33(Suppl P):331. (Abstr.)

11. Pipeleers, D. G., M. Marichal, and W. J. Malaisse. 1973. The stimulus-secretion coupling of glucose-induced insulin release. XIV. Glucose regulation of insular biosynthetic activity. Endocrinology. 93:1001-1011.

12. Henquin, J. C. 1979. Opposite effects of intracellular $\mathrm{Ca}^{2+}$ and glucose on $\mathrm{K}^{+}$permeability of pancreatic islet cells. Nature (Lond.). 280:66-68.

13. Ashcroft, F. M., D. E. Harrison, and S. J. Ashcroft. 1984. Glucose induces closure of single potassium channels in isolated rat pancreatic beta cells. Nature (Lond.). 312:446-448.

14. Cook, D. L., and C. N. Hales. 1984. Intracellular ATP directly blocks $\mathrm{K}^{+}$ channels in pancreatic B-cells. Nature (Lond.). 311:271-273.

15. Dean, P. M., and E. K. Matthews. 1970. Glucose-induced electrical activity in pancreatic islet cells. J. Physiol. (Lond.). 210:255-264.

16. Lin, B. J., B. R. Nagy, and R. E. Haist. 1972. Effect of various concentrations of glucose on insulin biosynthesis. Endocrinology. 91:309-311.

17. Thorens, B., H. K. Sarkar, H. R. Kaback, and H. F. Lodish. 1988. Cloning and functional expression in bacteria of a novel glucose transporter present in liver, intestine, kidney, and $\beta$-pancreatic islet cells. Cell. 55:281-290.

18. Meglasson, M. D., P. T. Burch, D. K. Berner, J. Najafi, A. P. Vogin, and F. M. Matschinsky. 1983. Chromatographic resolution and kinetic characterization of glucokinase from islets of Langerhans. Proc. Natl. Acad. Sci. USA. 80:8589.

19. Iynedjian, P. B., G. Mobius, H. J. Seitz, C. B. Wollheim, and A. E. Renold. 1986. Tissue-specific expression of glucokinase: identification of the gene product in liver and pancreatic islets. Proc. Natl. Acad. Sci. USA. 83:1998-2001.

20. McDonald, M. J. 1990 . Elusive proximal signals of $\beta$-cells for insulin secretion. Diabetes. 89:1561-1566.

21. Wolf, B. A., J. Florholmen, J. Twek, and M. L. McDaniel. Studies of $\mathrm{Ca}^{2+}$ requirements for glucose- and carbachol-induced augmentation of inositol triphosphate and inositol tetrakisphosphate accumulation in digitonin-permeabilized islets. Evidence for a glucose recognition site in insulin secretion. 1988. $J$. Biol. Chem. 263:3565-3575.

22. Orci, L., M. Ravazzola, M. Amherdt, O. Madsen, J.-D. Vassalli, and A. Perrelet. 1985. Direct identification of prohormone conversion site in insulin-secreting cells. Cell. 42:671-681.

23. Orci, L., A. A. Like, M. Amherdt, B. Blondel, Y. Kanazawa, E. B. Marliss, A. E. Lambert, C. B. Wollheim, and A. E. Renold. 1973. Monolayer cell culture of neonatal rat pancreas: an ultrastructural and biochemical study of functioning endocrine cells. J. Ultrastruct. Res. 43:270-297.

24. Van Schravendijk, C. F. H., L. Heylen, R. Kiekens, and D. G. Pipeleers. 1991. Heterogeneity in the secretory response of pancreatic B cells. Diabetes. 40(Suppl 1):177A. (Abstr.) 